\title{
Tordera River Delta system build up (NE Iberian Peninsula): sedimentary sequences and offshore correlation
}

\author{
Isabel Vila ${ }^{1}$, Jordi Serra ${ }^{1,2}$ \\ ${ }^{1}$ Departament d'EP i GM, Facultat de Geologia, Universitat de Barcelona, carrer Martí Franqués s/n, 08028 Barcelona, \\ Spain.E-mail: ivilapla7@alumnes.ub.edu (I.V.); jordi.serra@ub.edu (J.S.). \\ ${ }^{2}$ Institut de l'Aigua, Facultat de Dret, Universitat de Barcelona, Avda. Diagonal 684, 08034 Barcelona, Spain.
}

\begin{abstract}
Summary: The Tordera River Delta is made up of coarse sand bodies which were formed during the last sea level rise. Marine and land seismic profiles and wells show three depositional Holocene sequences corresponding to a) the transgressive base level, b) the progradant intermediate unit and c) the progradant unit which onlaps the Plio-Pleistocene sequence seawards and the granitic basement on the present delta plain and northern coast. The morphology of the sedimentary bodies, isobath maps and marine geophysical data enabled us to gain fresh insights into the evolution of the delta and its prodelta and into the various relict sand bodies on the inner shelf. The evolution of the coastline can be followed during the prograding process of the lower units from the successive coastal and internal lagoons. These coastal lagoons were conditioned by river changes and basement morphology. Once the sea level maximum was attained, the prograding units covered these morphologies, resulting in the present delta configuration.
\end{abstract}

Keywords: Holocene delta; Tordera River; seismic and sedimentary sequences; Blanes Canyon; coarse-grained delta.

Evolución del sistema deltaico del Río Tordera (NE de la Península Ibérica): secuencias sedimentarias y correlación mar adentro

Resumen: El Delta del Río Tordera está formado por cuerpos de arena gruesa depositados durante el último ascenso del nivel del mar. Los perfiles sísmicos marinos y terrestres muestran tres secuencias deposicionales holocenas correspondientes a: a) el nivel de base transgresivo, b) la secuencia intermedia progradante y c) la secuencia que prograda hacia mar sobre el substrato plio-pleistoceno y el zócalo granítico en la llanura deltaica. La morfología de los cuerpos sedimentarios, la cartografía en isobatas y los datos geofísicos submarinos nos ofrecen nueva información sobre la evolución del delta, prodelta y de los diferentes cuerpos relictos de arena de la plataforma interna. La evolución de la línea de costa puede ser seguida a lo largo del proceso progradante de las secuencias anteriores a partir de la sucesión de lagunas costeras e internas. La presencia de estas lagunas estaba condicionada por los sucesivos cambios fluviales y la morfología del substrato. Una vez alcanzado el máximo eustático, las unidades superiores progradantes recubren estas morfologías dando lugar a la actual morfología deltaica.

Palabras clave: delta holoceno; río Tordera; secuencias sísmicas y sedimentarias; Cañón de Blanes; delta de grano grueso.

Citation/Como citar este artículo: Vila I., Serra J. 2015. Tordera River Delta system build up (NE Iberian Peninsula): sedimentary sequences and offshore correlation. Sci. Mar. 79(3): 305-317. doi: http://dx.doi.org/10.3989/scimar.04188.07A

Editor: P. Puig.

Received: November 25, 2014. Accepted: May 29, 2015. Published: July 8, 2015.

Copyright: () 2015 CSIC. This is an open-access article distributed under the Creative Commons Attribution-Non Commercial Lisence (by-nc) Spain 3.0.

\section{INTRODUCTION}

The geometry and evolution of a delta are the consequence of the fluvial regime, the sediment grain size, the tectonics of the area and the oceanic system of the receiving basin (Liu et al. 2000, Pellegrini 2015). In addition to the classification of deltas as a function of the dominant processes in the delta front area (Wright and Coleman 1972, Galloway 1975), two important factors should be considered to account for delta dynamics: sediment supply and grain size. These factors influence the gradient and channel pattern of the delta plain, the type of shoreline and the response to wave energy and tidal regime, in addition to the resedimentation processes on the subaqueous delta slope (Macpherson et al. 1987, Postma 1990, Orton and Reading 1993). Consequently, the deltas formed under the environmental conditions of a sediment 
supply and a depositional gradient seawards yield a different depositional architecture in terms of grain size. Coarse sand deltas are characterized by a delta plain with two types of channel patterns: very high bed load channels (gravels) and bed load channels (coarse sand). When the very high bed load channels reach the coast, Gilbert-Type foresets are formed if the basin is sufficiently deep (Orton and Reading 1993). This is the case of the coarse-grained fan deltas, which have a mainly alluvial, lacustrine or glacial origin (Dunne and Hepton 1984, Corner et al. 1990, Martini 1990) or are subjected to significant tectonic influence (Bardaji et al. 1990). The bed load channels in the outflow tend to be concentrated in a network of bifurcating multiple channels separated by numerous bars (Orton and Reading 1993). This is the case on the Losna and Antnsjo sandy braid deltas (Bogen 1983). Along the Mediterranean coast, the coarse sand deltas described consist of gravel pleistocene-Holocene fan deltas influenced by recent tectonic and wave activity (Massari and Parea 1990, Dabrio et al. 1991, Pellegrini et al. 2015). Only two examples of sandy braid deltas have been cited: Goynuk Delta in the gulf of Antalya (Ayranci et al. 2010) and the Tordera delta, analysed here.

At regional level, the stratigraphic and sequential Holocene evolution of small delta systems of the Rivers Fluvià, Besós, Llobregat and Foix has been studied by several authors (Checa et al. 1988, Díaz and Ercilla 1993, Gámez et al. 2009, Velasco et al 2012). These deltas are similar in structure, development and sedimentary processes, with the exception of the coarsegrained Tordera and Besós deltas, both controlled by glacio-eustatic sea level changes, fault activity, and the action of waves and drift currents (Serra et al. 1985, Riba and Colombo 2009, Velasco et al. 2012). The Holocene sediments of the Besós delta are only represented by the upper units owing to the presence of a Plio-Pleistocene high which prevented the sedimentation of the transgressive lower units.

In the absence of studies about coarse sand deltas in the Mediterranean, the Tordera delta is a fine example of this delta type in microtidal conditions dominated by fluvial processes and littoral drift. The stratigraphic reconstruction of this specific whole delta system also offers new insights into its build-up and its chronology. Moreover, the permeability characteristics of coarse sand deltas make them a good geological model as possible oil reservoir. Therefore, given the scarcity of this type of deltaic bodies, the Tordera River is a unique case for studying this kind of formation in the sedimentary record.

Data integration of delta and submerged prodelta geophysical profiles and the detailed sequential study of on-land drills allow us to establish the correlation between units and sequences of the two domains. A chronology of the sedimentary sequences is proposed on the basis of these findings, and geographical distribution of the sedimentary units in addition to a paleogeographic reconstruction are also presented. The model distinguishes three sedimentary sequences: the lower, middle and present Holocene unconformably overlying the Plio-Pleistocene shelf materials and the granitic basement.

\section{GENERAL SETTING}

The River Tordera flows into the sea between Malgrat de Mar and Blanes in the NE of the Iberian Peninsula. The upper and middle sectors of the River Tordera follow the trench between the Littoral and PreLittoral Cordilleras before veering to the SE and then crossing the coastal range (Serra 1976). The Tordera has a basin area of $879 \mathrm{~km}^{2}$ and a length of $59 \mathrm{~km}$, and its delta aerial surface is $4.2 \mathrm{~km}^{2}$. The river has a typical Mediterranean regime with $7.2 \mathrm{~m}^{3} \mathrm{~s}^{-1}$ mean water discharge, long dry summers and sporadic floods and spring time (Martín-Vide and Llasat 2000, Condal and Ullastres 1996) as registered at Can Serra of up to 1280 $\mathrm{m}^{3} \mathrm{~s}^{-1}$ (ACA 2002) and also at Fogars de Tordera of up to $1836 \mathrm{~m}^{3} \mathrm{~s}^{-1}$ (Liquete 2008). The delta is mainly composed of coarse sand derived from granitoid and metamorphic rocks of the pre-littoral mountains. Because of the coarse texture of the sand, the Tordera delta is characterized by a high permeability that facilitates water infiltration into the delta plain, by the presence of a well-developed coarse sand beach mouth bar (most of the time between floods), and by a high gradient delta front (up to $23^{\circ}$ ). Sediment supply is carried mainly during high regimes as bed load $(>75 \%)$ and only less than $20 \%$ as suspended load (Rovira et al. 2005). The total contribution of sediment to the sea has been calculated by a number of authors using different methods. Considering the littoral drift necessary to feed the relict sedimentary bodies on the continental shelf, the sediment carried can attain $200000 \mathrm{~m}^{3} \mathrm{a}^{-1}$ (Copeiro del Villar 1982, Serra et al. 2007). According to Rovira et al. (2005) the river bed load sediment transport amounted to $21500 \mathrm{~m}^{3} \mathrm{a}^{-1}$.

The Tordera fluvial-deltaic system resulted from the pulsations of the Holocene sea level rise (between 11 and $6.6 \mathrm{Ka}$ ) that led to successive deltaic sequences culminating in the current Tordera delta. These sequences range from a depth of $60 \mathrm{~m}$ to the present delta front, which currently progrades over the basal transgressive sequences. Geophysical surveys (Teixidó 2000, Falgàs 2007) and deep wells for the Tordera desalination plant (Serra et al. 2007) have considerably improved our understanding of the structure and evolution of the Tordera delta system. The morpho-dynamic and structural study of the submerged continental shelf has been undertaken by several authors (e.g. Serra 1976, Díaz and Maldonado 1989, Duran et al. 2013, 2014), who have contributed to the knowledge of sedimentary processes and the eustatic evolution that affected the submerged continental shelf linked to the present delta formation.

The River Tordera gives rise to the Maresme sedimentary coastal cell (Fig. 1), which extends to the River Besos, $50 \mathrm{~km}$ to the SW. The sediments that reach the mouth of the Tordera are redistributed mostly by the dominant wave climate to the southwest or descend the steep delta talus. The impact of other dynamic factors, such as geostrophic currents and the action of the tides, are negligible (Font et al. 1987, Sorribas et al. 1993, Grobas 2003). In the case of high energy events, part of these sediments may be transported to the internal shelf 


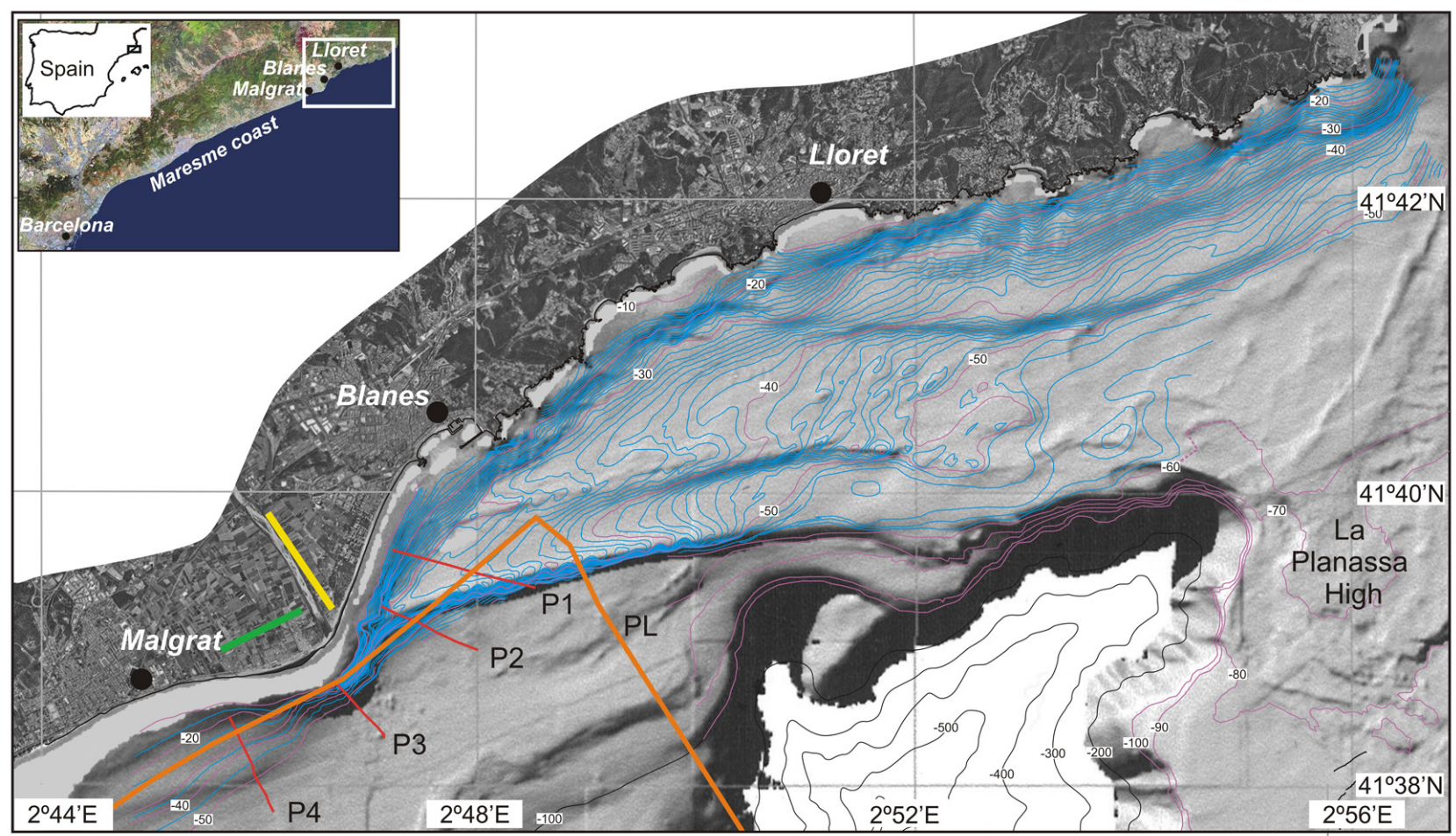

Fig. 1. - Study area. Physiographic map of the Tordera Delta, internal shelf and head of Blanes Canyon. Bathymetric contour interval is 5 metres between 0 and 80 metres depth (UB 2012 survey), complete with data from several sources: Beachmed (Alonso et al. 2008), HitmaPerfibesa (in Alfaro 2011) and Lastras and Euroleon (2011). In red and orange, respectively, situation of seismic profiles P (Serra et al. 2007) and PL (Díaz and Maldonado 1989). In green and yellow the aerial seismic profiles from Teixidó (2000) and Falgàs (2007) respectively.

and Blanes Canyon head zone (Zúñiga et al. 2009, Pedrosa-Pàmies et al. 2013). The effect of the dense water currents (DSW cascading) is also low on the prodelta and surrounding shelf (Lastras and Euroleon 2011).

The wave climate is dominated by a NE to E regime, which shaped the coast and the existing relict sand bodies on the shelf (Díaz and Maldonado 1989, Serra et al. 1990). This regime accounts for the significant accumulation of relict sands during the last low sea level along the Maresme shelf to the SW of the River Tordera. Towards the Blanes Canyon head, only two main sand bars are distinguished (Fig. 1). A transverse sediment transport component must be taken into account given the high wave reflectivity of this coast.

\section{METHODS}

Sequential stratigraphy was used to better understand the evolution of the Tordera River Delta and the sedimentary bodies on the continental shelf, following the approach developed by Catuneanu et al. (2009). The findings offer new insights into the facies distribution, the geometry of the strata, and the major surfaces, establishing a chronological order of the basin infill. To this end, we integrated our data with other diverse data sources in order to identify depositional trends and sedimentological patterns of this environment.

The following types of data were used in this study: land wells, marine and land seismic profiles, bathymetry (single and multibeam) and side scan sonar. Side scan sonar is a specialized system for investigating the seafloor morphology: it transmits sound energy and analyses the return signal (echo) that has bounced off the seafloor. The transmitted energy is shaped into a fan that sweeps the seafloor from directly under the towfish to either side. The strength of the return echo is continuously recorded, creating an image from the ocean botton (background structures) that is comparable to aerial photography on land (Able et al. 1987).

\section{Delta plain}

The internal structure and the stratigraphy of the Tordera delta were analysed using two high-resolution seismic profiles (Fig. 1, Teixidó 2000, Falgàs 2007) and a network of 50 land wells (Fig. 2) (ACA 2002, Sufi-ACA 2008, Perfibesa-ACA 2001-2002). Seismic data were acquired using a 48-channel digital seismograph, 40-Hz geophones and 5-m shot and receiver spacing (Texidó 2000, Falgàs 2007). Out a total of 77 land wells, 50 were selected for this study, considering depth and number of identified units. The land wells show alternations of fine sediments, sands, and gravels, and are described in the results section. New textural and sedimentological arguments such as fine sediment content were considered in the stratrigraphic interpretation of the wells. This interpretation sheds light on the paleogeographic Holocene evolution of the delta, enabling us to obtain a 3D view of the structural and environmental distribution of the delta.

\section{Prodelta and shelf}

The geomorphology of the Tordera prodelta and internal shelf was determined by integrating bathymetric data from the earlier projects ESPACE and Beachmed- 


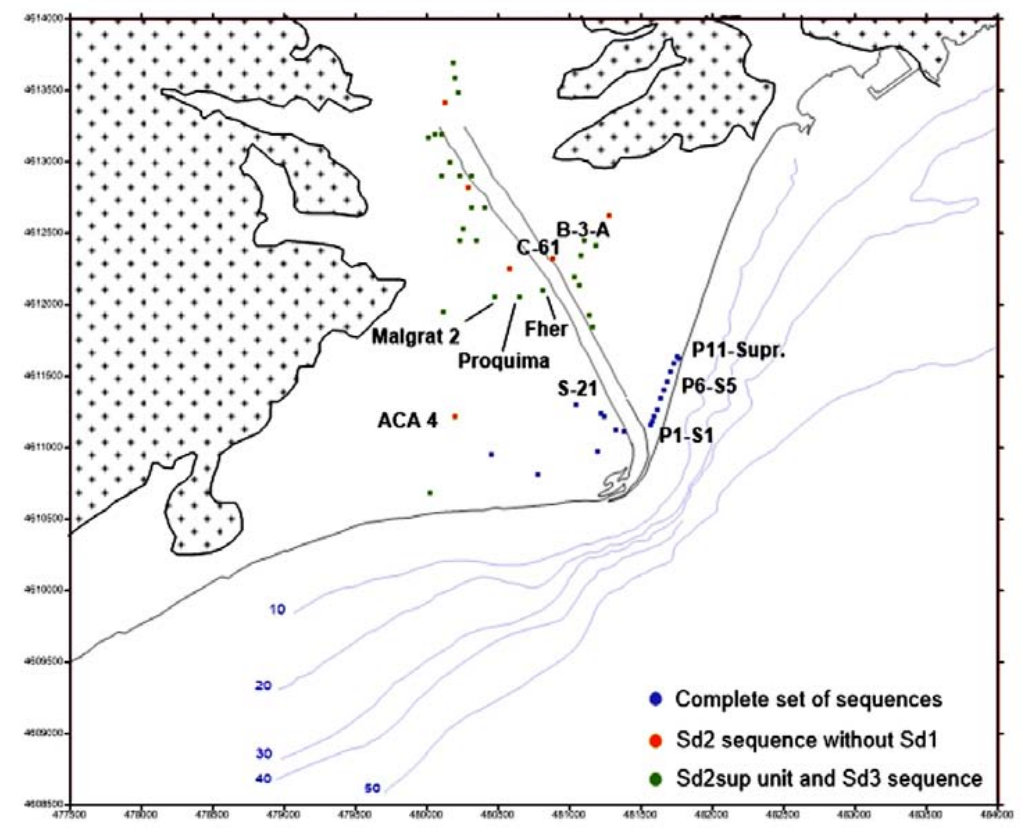

Fig. 2. - Situation Map of the 50 wells and piezometers on the Tordera Delta plain under study. The colours indicate the different types of well classified as a function of the number of stratigraphic sequences and units present.

GESA-UB and present bathymetric works from UBCEAB using a SIMRAD EM3000D, a SeaBeam 1185 echo sounder with a frequency of $80-125 \mathrm{khz}$ and a Garmin 76CSx GPS map (Fig. 1).

The internal structure was studied using high-resolution Geopulse/UNIBOOM 350 J (P1-4) Sparker 3kJ (PL) seismic profiles (Fig. 1), which were reinterpreted by applying new sequential stratigraphy criteria.

\section{RESULTS}

The sedimentary units are described in this section with respect to their present situation onshore and offshore. The methods for land and sea domains are well data and seismic profiles, respectively.

\section{Delta plain}

Three stratigraphic sequences were differentiated from base to top: Sd1, Sd2 and Sd3. Sequence Sd1 lies unconformably over a pre-Holocene substrate or over the granite basement. This basement is especially significant since it plays a major role in the transgressive units and contributes to our understanding of the evolution of the present delta. There are two structural highs of the basement on the delta front and northeast delta plain sector (Perea 2006), as shown on seismic profiles from Teixidó (2000) and Falgàs (2007), well data units and basement distribution. These highs are limited by faults and exert a paleogeografic control over the deposition and distribution of the lower holocene units.

The sequences are coarsening upwards and have two sedimentary units for $\mathrm{Sd} 1$ and three for $\mathrm{Sd} 2$ and Sd3 (Fig. 3). The limits between the sequences were deduced from textural and geophysical changes using sedimentological data such as the net contact between the upper coarse detrital sequence material and clay or lime at the base of the upper sequence. Although these contact surfaces must be regarded as heterochronous (transgressive or prograding), they also serve as a reference level for correlation purposes.

In the frontal area of the delta, sequence $\mathrm{Sd} 1$ is made up of two units, Sd11l and Sd1sup from bottom to top (Fig. 3). Sd11l consists of grey silt in the southern hemidelta and silt and grey clay in the northern one. In the internal area of the delta plain, the unit changes laterally to sandier facies (Fig. 2, S-21 without unit Sd11l and ACA 4).

In the southern hemidelta, Sd1sup shows alternating coarse detrital levels, some of them with bivalve fragments, levels of grey silty clays and levels of silt near the present delta front. Towards the internal delta, this unit consists of silt, sand and silty sand (well S-21, ACA 4, Fig. 2). In the northern hemidelta, which is made up of coarse detrital materials, a lateral facies change can be deduced: the wells closer to the mouth have coarser lithologies (gravel and pebbles P1-S1 well, Fig. 2), whereas those further away show alternating levels of sandy gravel with or without interstitial clay (P6-S5 well, Fig. 2). Clay or silt levels are absent. Granitic basement was reached at depths of between 70 and more than $150 \mathrm{~m}$ in the surrounding wells in the front of the delta plain (wells S-21 and P6-S5, respectively).

The Sd2 sequence (Fig. 3) is composed of three units: Sd21l, Sd2p and Sd2sup from bottom to top. Sd2ll is located in the front part of the delta and consists of fine to very fine sand and grey silt. Towards the delta plain, Sd2ll changes sideways to sandier lithologies, as at well S-21. Sd2p consists of medium sands, gravel, clay and brown silt. This unit is found throughout the delta plain, except in the northeastern part because of the presence of a structural high of the basement at 20-24 m (well B-3-A, Fig. 2). Sd2sup consists of coarse sand, gravel 


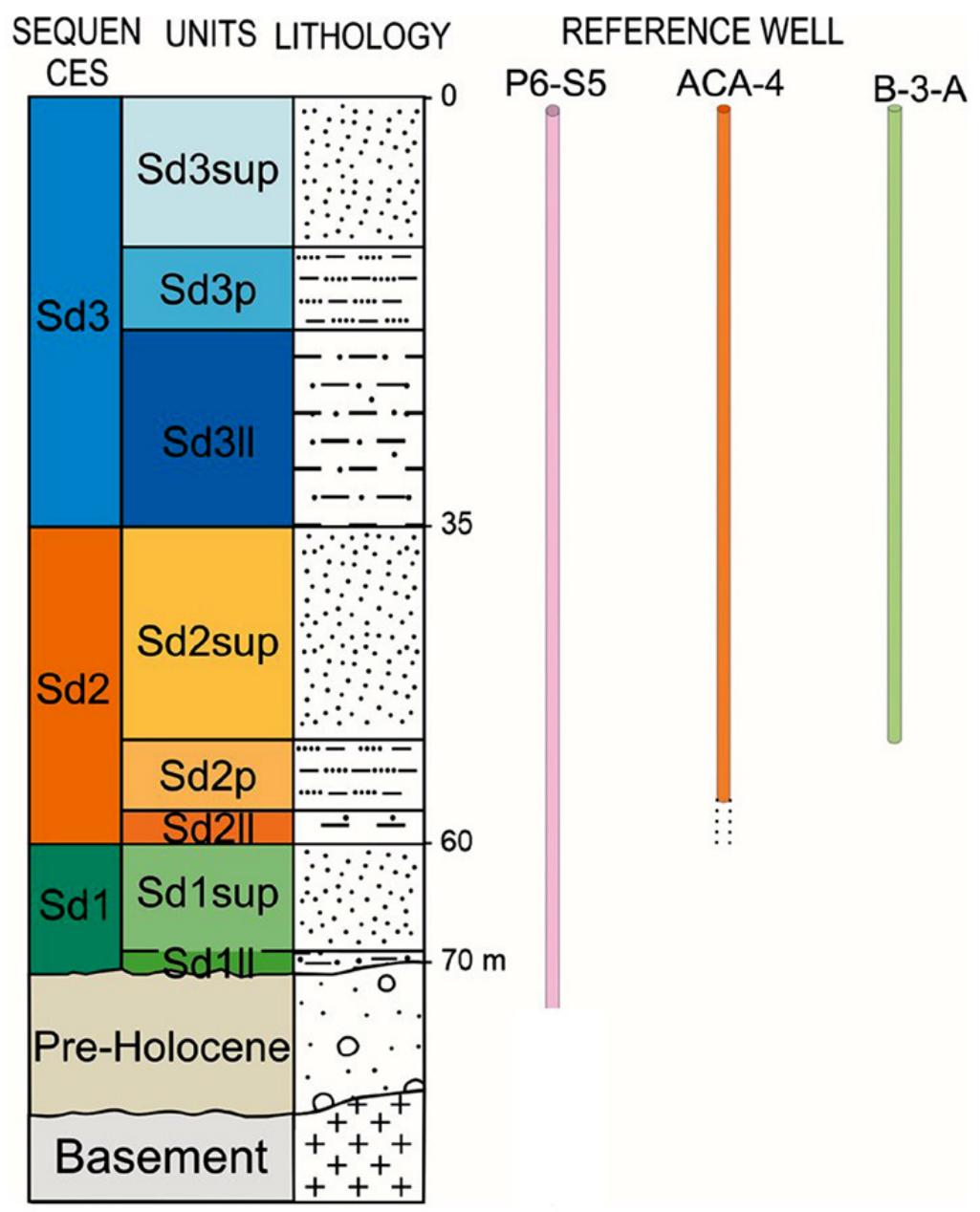

Fig. 3. - Standard lithological reference section and depths (comprising all units) of the Tordera Delta Holocene sequences, as recorded at the P6-S5 well. The map in Figure 2 shows the three well types as a function of the sequence content: pink contains all the sequences (as in P6-S5 well), orange does not contain Sd1-Sd21l (as in ACA-4 well), and green only contains Sd3 and Sd2sup sequences (as in B-3-A well).

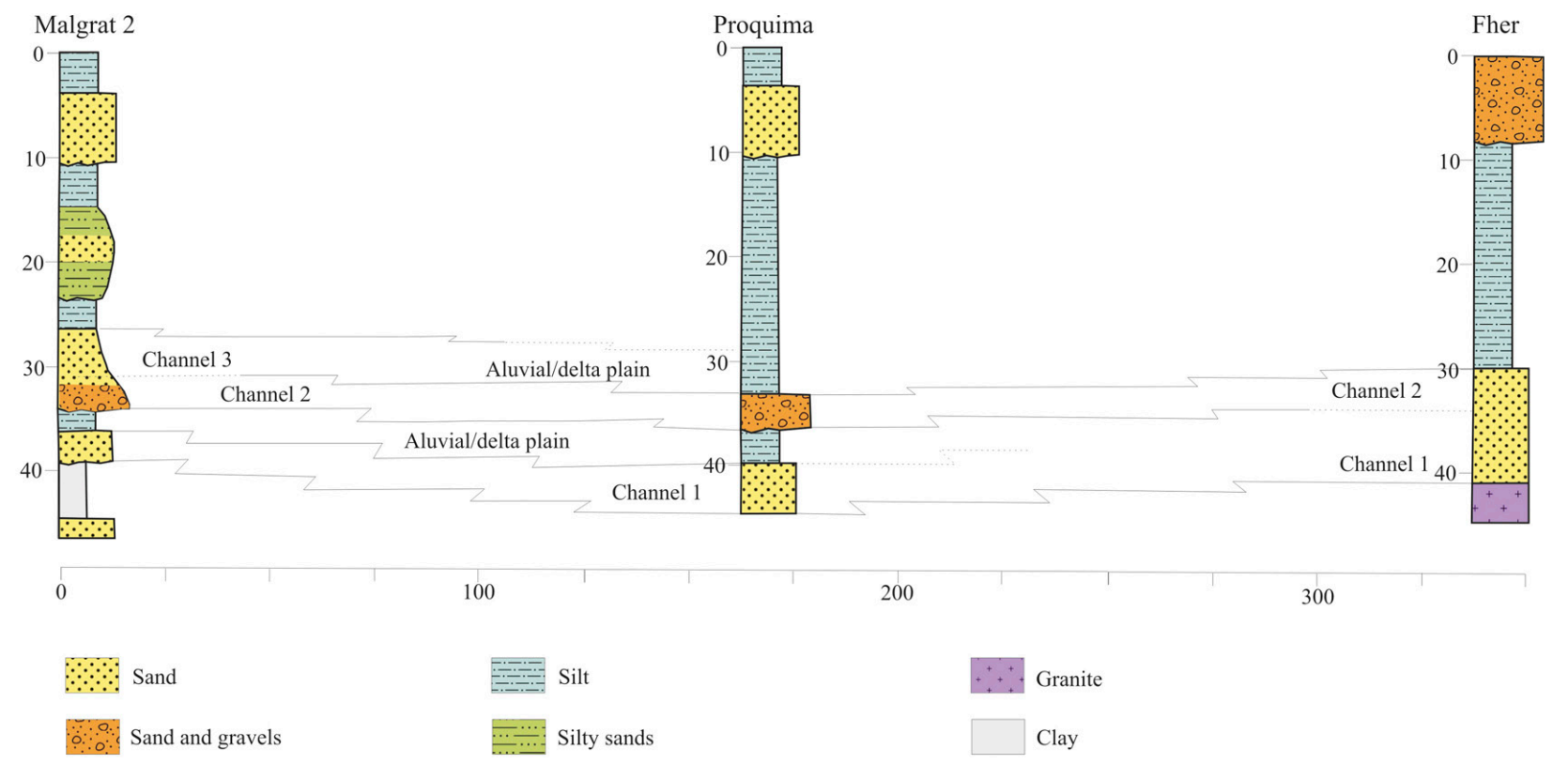

Fig. 4. - Interpretation of Sd2sup. as successive channels forms and overflow deposits between wells Malgrat 2, Proquima and Fher (situation in Fig. 2). 


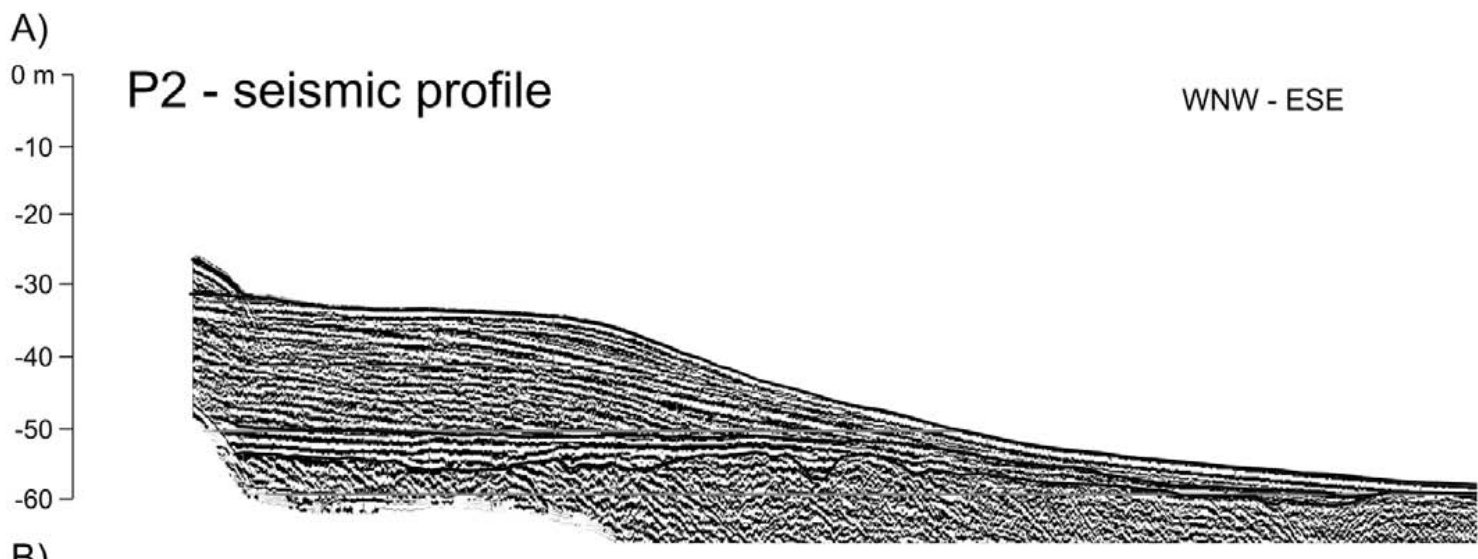

B)

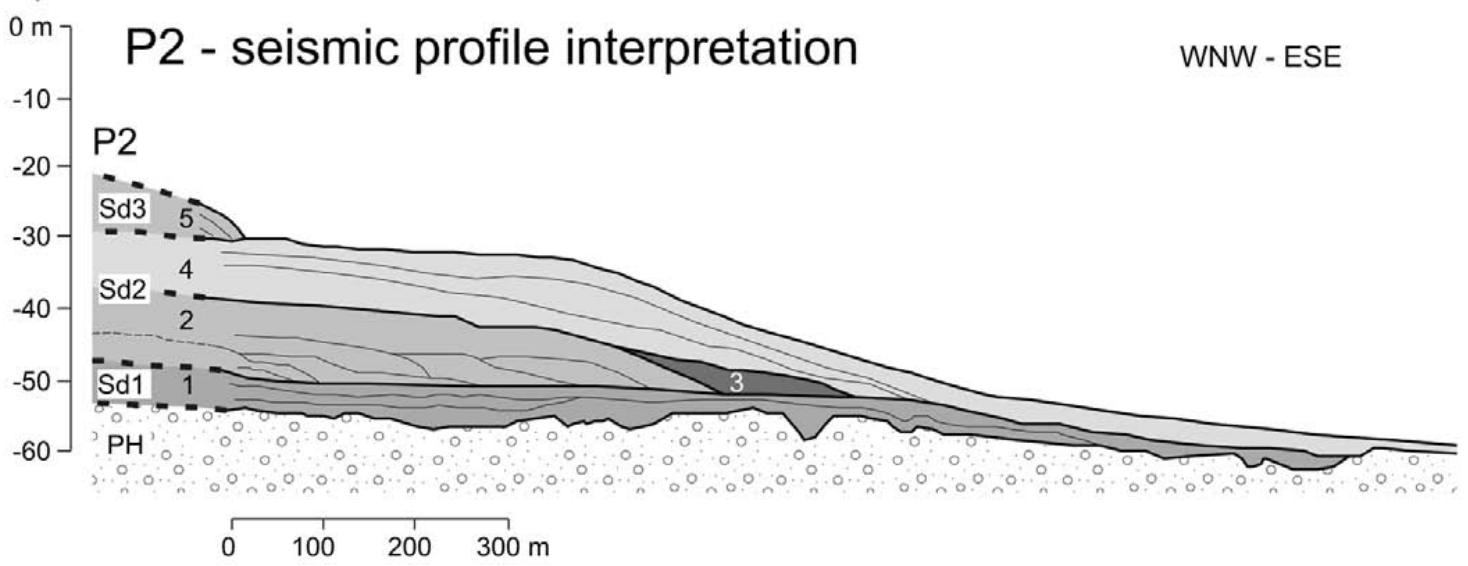

Fig. 5. - Sequence boundaries and internal reflection configuration from profiles P1 to P4 (see Fig. 1 for situation), including seismic reflection patterns (aggradation) and terminations (toplap, downlap and coastal onlap).

and silt, displaying coarsening-upwards sequences. Sd2sup is the first unit present in the entire Holocene delta (Fig. 2). From the correlation between nearby wells, it can be deduced that these materials were deposited in a fluvial environment, as evidenced by their channel and overflow facies and geometry (Fig. 4).

Sequence Sd3 (Fig. 3) comprises three units from bottom to top: $\mathrm{Sd} 311, \mathrm{Sd} 3 \mathrm{p}$ and $\mathrm{Sd} 3$ sup. Sd31l occurs in two sectors of the delta: at the front of the delta plain (subunit Sd3111) and on the northern delta plain (subunit Sd3112). In the southern hemidelta, Sd31l1 consists of grey-black clays with organic matter and vegetal remains. In the northern hemidelta, this unit is more variable with alternating sandy grey clay, silt and bioclasts, bivalves, brachiopods and gastropods (well P11-Supr.). Subunit Sd3112 is made up of dark-grey silt with abundant organic matter, but with no marine bioclasts (well B-3-A). Subunits Sd3111 and Sd3112 change to coarse sandy lithologies towards the delta plain. Unit $\mathrm{Sd} 3 \mathrm{p}$ is coarser than unit $\mathrm{Sd} 3111$, with levels of fine and medium sands, gravel, silt and clay deposits. The Sd3sup unit is mainly detrital in the upper delta plain, displaying a lateral change to fine and well-classified sands towards the internal plain.

\section{Prodelta and shelf}

The analysis of the high-resolution seismic profiles (Fig. 1 for location) allows us to differentiate four seis-

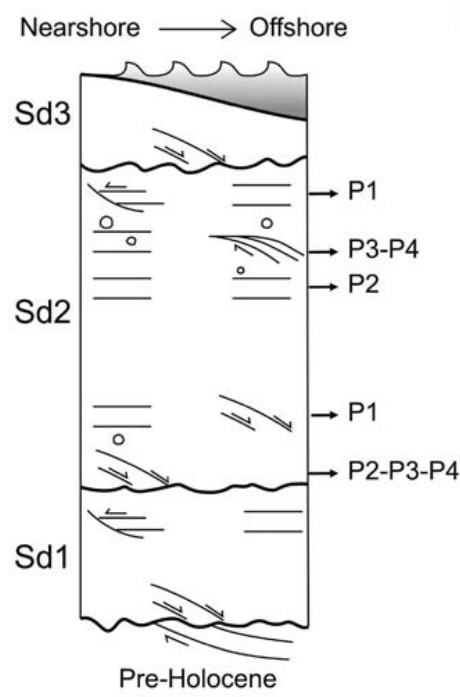

Internal configuration

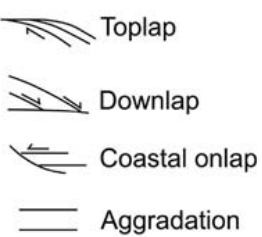

Sequence limits

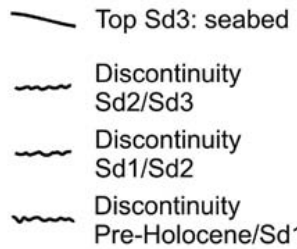

Fig. 6. - A, seismic profile P2. B, the line drawing of Profile P2 shows three internal configuration types: a) 1 corresponding to the base of transgressive levels (TST), b) clinoforms with sigmoidal morphology in 2, 5 (HST) and 4 (LST) and c) a wedge morphology in 3 (FSST). PH: substrate.

mic sequences: a lower sequence $(\mathrm{PH})$ and the upper sequences $\mathrm{Sd} 1, \mathrm{Sd} 2$ and $\mathrm{Sd} 3$, each one formed by internal units. These sequences are defined by their erosive (top of $\mathrm{PH}$ ) or unconformable limits ( $\mathrm{Sd} 1-\mathrm{Sd} 2$ and $\mathrm{Sd} 2-\mathrm{Sd} 3$ ) and internal reflection configuration (Fig. 5). 
Basal sequence $\mathrm{PH}$ is characterized by sigmoidal morphology reflectors seaward and onlaps the surface towards the coast in contact with the granitic basement. Unit PH is eroded in its upper part, showing an irregular topographic surface. The limits between upper sequences ( $\mathrm{Sd} 1-\mathrm{Sd} 2$ and $\mathrm{Sd} 2-\mathrm{Sd} 3$ ) are unconformable (Fig. 5). Internally, Sd1 displays a basal onlap and downlap relationship and aggrading to sigmoidal reflections (Fig. 6). It is interpreted as an accretionary system tract (TST) based on its internal configuration and reflection terminations.

The lower boundary of $\mathrm{Sd} 2$ corresponds to a discontinuity defined by an onlap surface towards the coast that evolves seawards to a downlap surface. $\mathrm{Sd} 2$ comprises three internal units (units 2 to 4, from older to younger) that differ in development and distribution (Fig. 5). Unit 2 is formed by clinoforms with oblique progradational and aggrading configurations (Fig. 6). Unit 3 is a wedge-shaped seismic unit that sits basinward downlapping onto unit 1 , and it is interpreted as a falling stage system tract (FSST). Unit 4 shows aggrading and onlap reflectors from the coast to downlap on the $\mathrm{Sd} 1$ sequence seawards, where the morphology is a sigmoid-oblique. This prograding unit is interpreted as a low-stand system tract (LST). Sd3 consisting of only unit 5, displays a wedge-shaped geometry internally defined by seawards downlapping clinoforms, suggesting that it was formed in a late stage of sea level rise (HST), resulting in progradation and aggradation of coastal sand bodies. This unit corresponds to the top lap delta unit.

These seismic sequences (see Fig. 5 for system tract order) constitute the progressive transition from an HST (corresponding to unit 2), an FSST (unit 3) and an LST (unit 4) to the present HST (unit 5). It should be noted that, in profile P-2, Sd1 corresponds to a transgressive level (TST-1). Transgressive levels are not present in sequences $\mathrm{Sd} 2$ and Sd3 because of one of the following factors: a) the erosion of earlier transgressive levels, b) a thickness below the limit of seismic resolution, and c) a sea level rise that does not exceed the sediment supply, resulting in a continuous progradation. The base of the TST (Sd1) and the lower limits of the HST are used to make the correlation with the sedimentary sequences described on the onshore wells, and to make the correlation with the different sand bodies on the offshore (Fig. 7).
A)
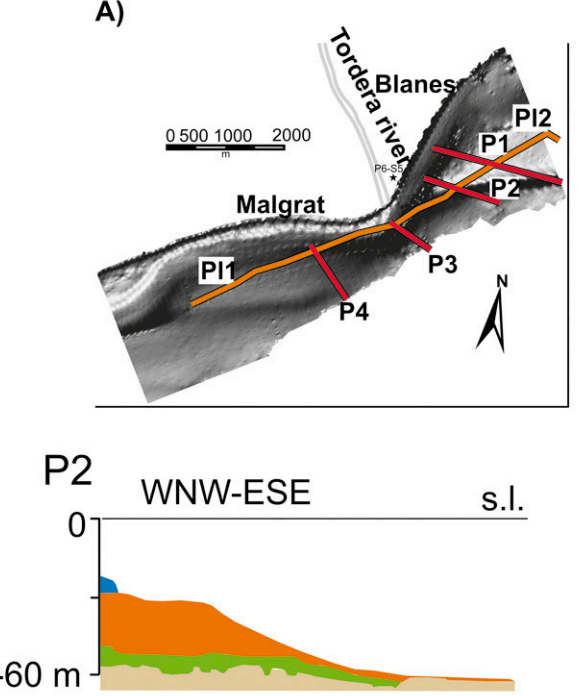

B)

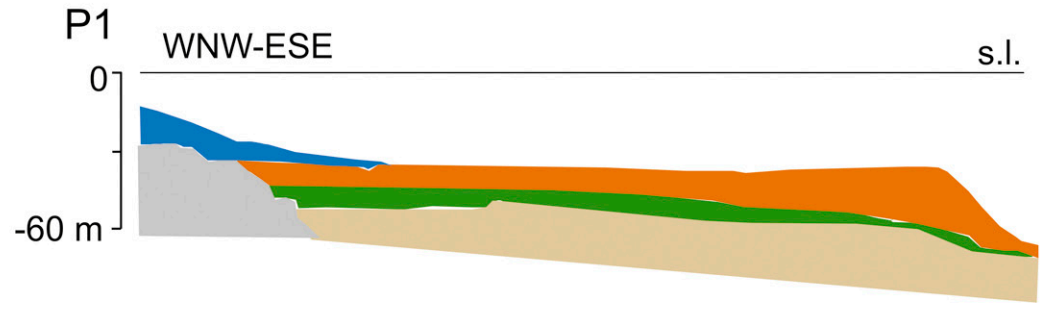

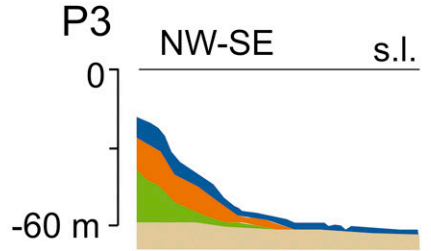

S.I.

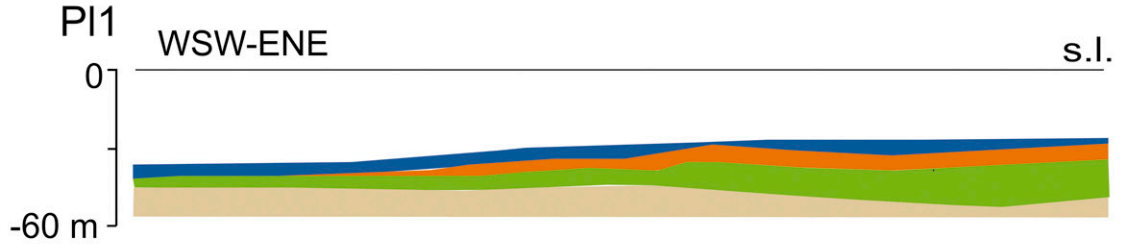

Pl2

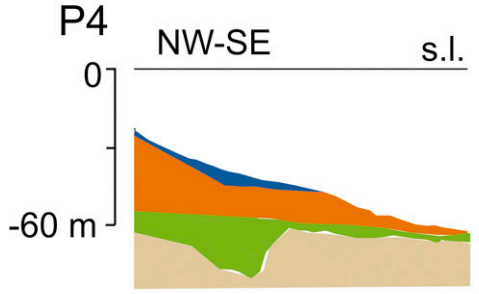

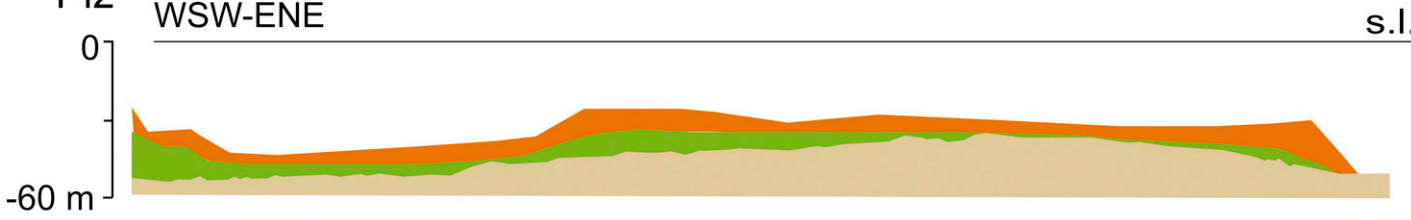

Fig. 7. - A, image of slope gradients (modified from UB-Pridesa in Alfaro 2011) and situation of different seismic profiles: P1-P4 and PL. B, interpretation High-resolution seismic profile (see Fig. 5) showing three sequences Sd1, Sd2 and Sd3, PH and basement of the Tordera prodelta and inner shelf. A large paleochannel on the erosive base of Sd1 can be distinguished on P4. 


\section{SYNTHESIS AND DISCUSSION}

\section{Units, evolution and chronology}

As regards the delta systems in the NW Mediterranean, it may be affirmed that the eustatic and climatic processes dating from the postglacial transgressive level are common to all deltas. Some parallels may be drawn from the deltas of the Rivers Llobregat, Besós, Tordera and Rhone, (Gámez et al. 2009, Velasco et al. 2012, Boyer et al. 2006, in Fig. 8).

The boundaries between PH-Sd1, Sd1-Sd2, Sd2$\mathrm{Sd} 3$ and $\mathrm{Sd} 311-\mathrm{Sd} 3 \mathrm{p}$ are equivalent to the transgressive surface and stabilization depths defined at 70, 60, 38 and $22 \mathrm{~m}$ by the above authors, with slight differences in the chronology of units and levels.

In order to determine the differences and similarities between the aforementioned delta examples, the morphoclimatic, sedimentological and dynamic factors of the respective fluvial basins should be considered (Table 1).

This table highlights two prominent features: a) the volume of the river discharge (average and maximum), which accounts for the transport capacity and valley excavation-aggradation rate of the river; and b) the lithology of the fluvial basin, which determines the typology of the river sediment. This is the case of the Besós River Delta, where the transgressive surface at the delta mouth is only $30 \mathrm{~m}$ deep, whereas it is 60$70 \mathrm{~m}$ in the Llobregat, Tordera and Rhone deltas. This significant difference is attributed to the low river discharge and to the low capacity of excavation, which gives rise to the presence of a Plio-Pleistocene delta basement and is absent in the above examples (Table 1 ). The second feature accounts for the river sediment characteristics such as fine content and bed load transport, resulting in the prodelta sedimentation and in the presence of a delta aquitard. This is the case of the Llobregat, Besòs and Rhone deltas, with the exception of the Tordera coarse sand delta, where there is no formal aquitard. The second characteristic also accounts for the differences in unit chronology and depth because of the different aquitard structure and the subsidence rate as a function of this structure.

The correlation between land and marine sequences was carried out using the nearest wells on the coast (wells of Sufi-ACA 2008, Perfibesa-ACA 2001-2002) and the seismic data offshore. The boundaries between sedimentary sequences of the Tordera delta and the inner shelf are represented in a graphical model (Fig. 9). The model sections show the evolution of the Tordera

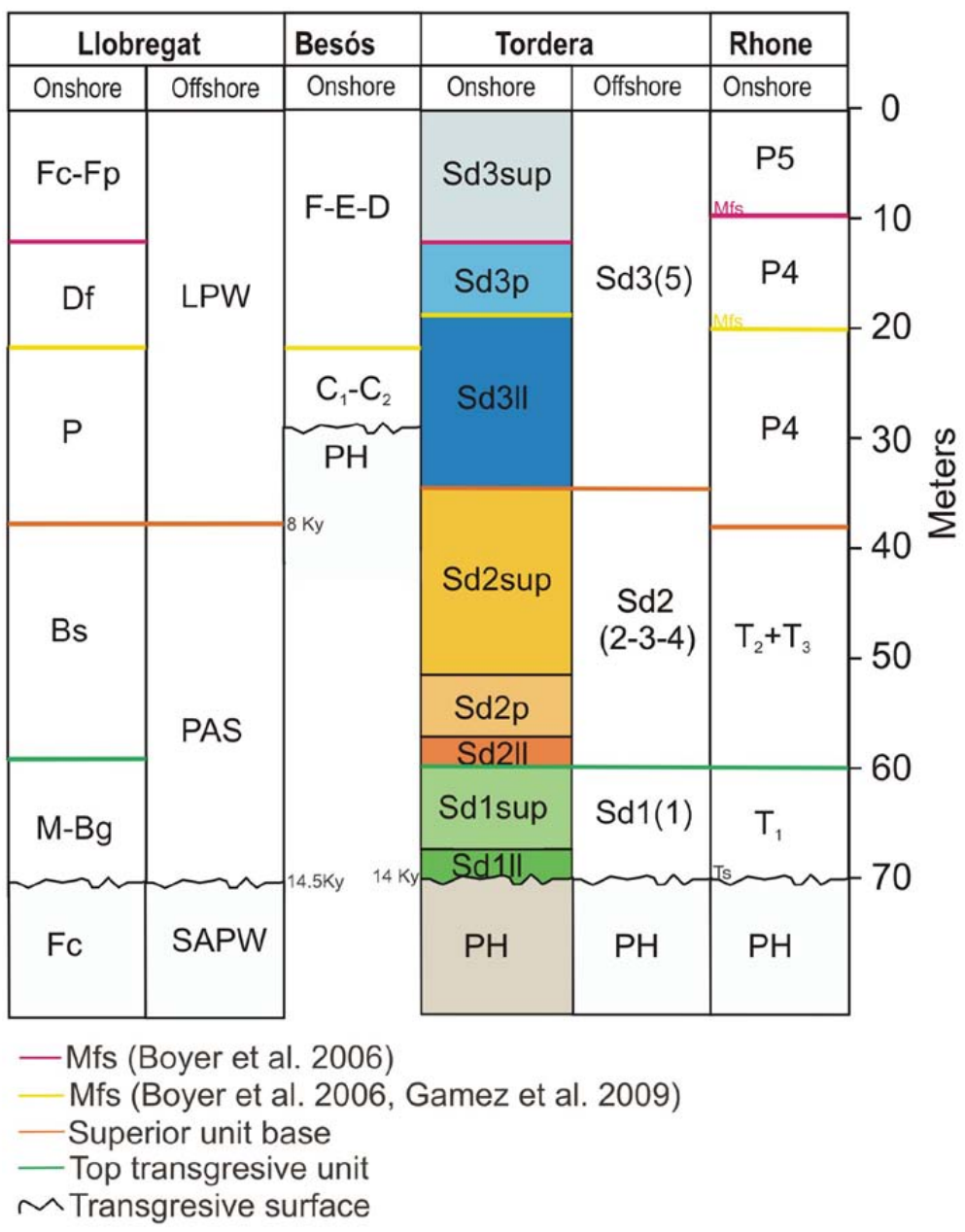

Fig. 8. - Comparison of other deltas in the NW Mediterranean with the Tordera delta. Four surfaces with a regional extension are observed: Mfs (in fuchsia and yellow), the top of transgressives units (in green), the top of Sd2 sequence (in orange) and the transgressive surface. 
Table 1. - Some characteristics of the Llobregat, Besós and Tordera rivers and deltas showing the main differences (modified from Liquete 2008). The lithology (\%) are: Hard Rock, Consolidate Sediments and Alluvial Sediments.

\begin{tabular}{|c|c|c|c|c|c|c|}
\hline \multirow[b]{2}{*}{ Delta } & \multirow{2}{*}{ Delta area $\left(\mathrm{km}^{2}\right)$} & \multirow{2}{*}{ Basin area/Length } & \multirow{2}{*}{$\begin{array}{c}\text { Discharge: } \\
\text { average/max }\left(\mathrm{m}^{3} \mathrm{~s}^{-1}\right)\end{array}$} & \multicolumn{3}{|c|}{ Lithology (\%) } \\
\hline & & & & HR & $\mathrm{CS}$ & AS \\
\hline Llobregat & 80 & $5045\left(\mathrm{~km}^{2}\right) / 163 \mathrm{~km}$ & $16.3 / 1600$ & 6 & 86 & 7 \\
\hline Besós & 8.3 & $1029\left(\mathrm{~km}^{2}\right) / 52 \mathrm{~km}$ & $6.8 / 270$ & 30 & 47 & 21 \\
\hline Tordera & 4.2 & $879\left(\mathrm{~km}^{2}\right) / 59 \mathrm{~km}$ & $7.2 / 1836$ & 68 & 17 & 13 \\
\hline
\end{tabular}
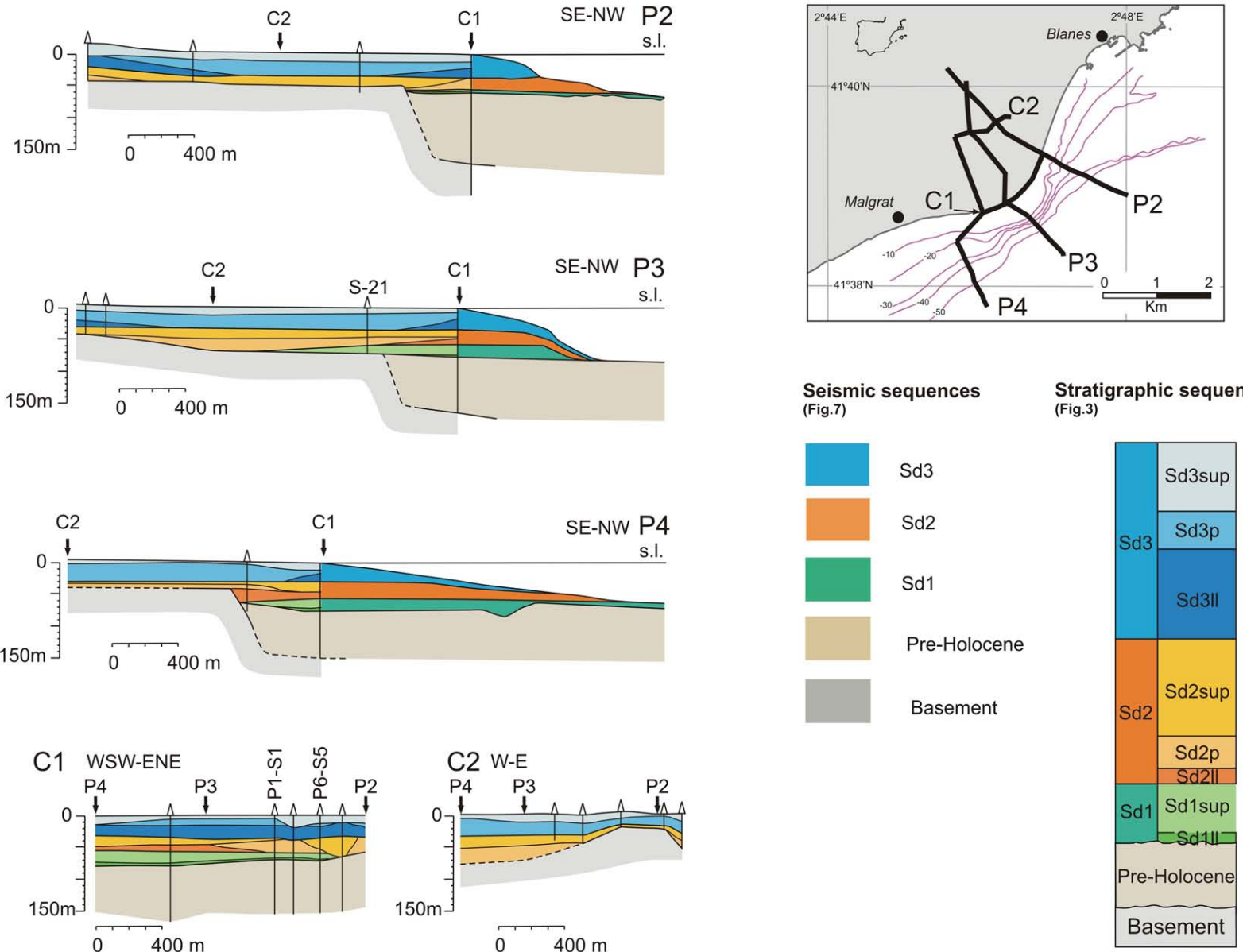

Fig. 9. - Correlation between deltaic sedimentary units and marine seismic sequences.

delta system and some aspects of the location of the sedimentary units: e.g. pelitic units $\mathrm{Sd} 3111$, Sd21l and Sd11l observed on the present delta front. The sea level rise did not exceed the height of the granite basement, with the result that the Sd3111, Sd21l and Sd11l pelitic levels were subsequently covered by the upper detrital units ( $\mathrm{Sd} 3 \mathrm{p}, \mathrm{Sd} 2 \mathrm{p}, \mathrm{Sd} 1 \mathrm{sup}$ ) sedimented in the subsequent prograding and aggradational deltaic environments.

Deltaic sequences $\mathrm{Sd} 1, \mathrm{Sd} 2$ and $\mathrm{Sd} 3$ show continuity seawards with the present relict sedimentary bodies. Four sectors may be differentiated on the basis of the morphological characteristics: A) the Tordera prodelta and Malgrat platform sector, B) the rocky shore littoral prism from Lloret de Mar to Tossa, C) the inner shelf between the Tordera prodelta and the Blanes Canyon, and D) the Blanes Canyon head (Fig. 10).

The analysis of bathymetric, Side Scan Sonar and high-resolution seismic profiles revealed the submerged morphological features, structure and distribution of the sedimentary units in the prodelta and shelf as far as the Blanes Canyon. The inner continental shelf of The Malgrat sector (Fig. 10) at the base of the steep delta front displays alobeted morphology body, A1, which descends gently to a depth of $60 \mathrm{~m}$. A2 corresponds to the present delta front and the high gradient slope characterized by the presence of gravitational sand avalanches and traces of grain flows, as shown in side scan sonar profiles (Serra and Montori 2003, Parra 2006).

Two detrital bodies, $\mathrm{C} 2$ and $\mathrm{C} 1$, extend to the E-NE between the steep east delta front and the head area of the Blanes Canyon, descending respectively to depths of 35 and $52 \mathrm{~m}$, as shown in profile P1 (Fig. 7). The front of these two bodies is similar to the delta front and the Malgrat ridge bar or spit (Serra et al. 2007), attaining a gradient of up to $23^{\circ}$ and a drop of 7 and 20 $\mathrm{m}$, respectively. This sector also displays outcrops of a pre-Holocene substrate that could have conditioned the morphology and the size of these detrital sand bodies (Serra 1976). 


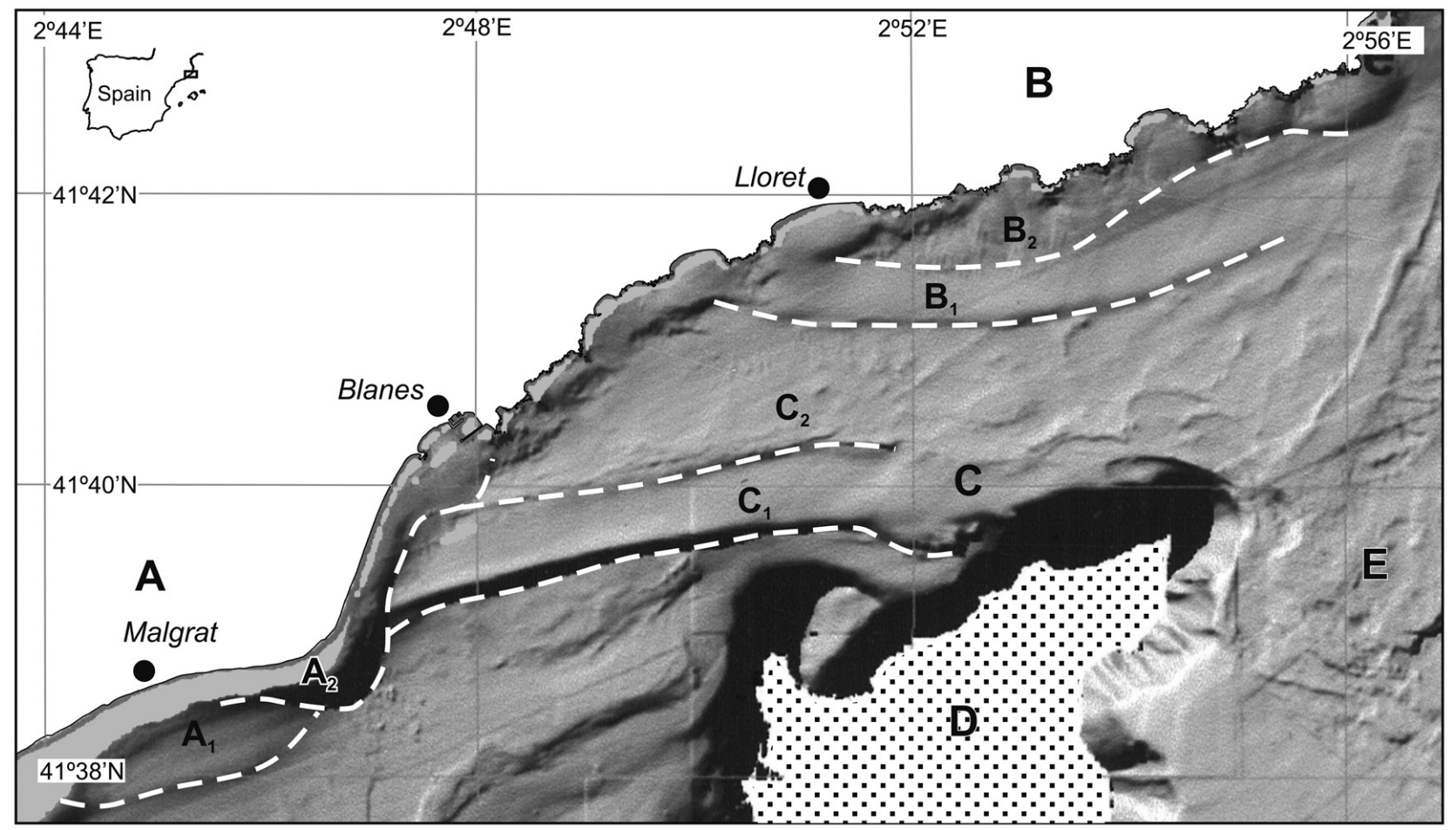

Fig. 10. - Morphology scheme of the continental shelf between the Tordera River prodelta and the Blanes Canyon head obtained from multibeam (ESPACE-IEO project). Four sectors are distinguished: A, prodelta and relict lobe of Malgrat sector (A2 and A1, resp.); B, Lloret-Tossa littoral prisms (B1 and B2); C, relict sand bodies on the inner continental shelf between the prodelta and Blanes Canyon Head(C1 and C2); D, Blanes Canyon; and E, Planassa High (Serra-Raventós and Got 1976).

The sedimentary bodies B2 and B1 (Fig. 10) correspond to the present and to the relict high gradient littoral prisms, respectively. These bodies consist of detrital input from the streams of the locality (Tossa - Blanes).

The morphology of the transgressive clastic units is consistent with the marine dynamic regime that existed during the last eustatic rise, and this regime is similar to the present one (Serra 1976). Relict forms, the internal structure and the morphology of the sea floor (Fig. 10 and Fig. 6) offer new insights into the evolution of the fluvial-deltaic River Tordera system during the Holocene transgression. During the eustatic rise, the resulting bed forms migrated upwards to lower depths. The first Holocene delta lobe, A1, corresponds to sequence $\mathrm{Sd} 1$. The $\mathrm{C} 1$ and $\mathrm{C} 2$ sand bodies are characterized by an external steep seaward slope and an internal concave morphology towards the mainland (Figs 1 and 10) and can be correlated with $\mathrm{Sd} 2$ and $\mathrm{Sd} 3$, respectively. These features bear a striking resemblance to those described in the spit at the mouth of the River Tordera (bar of Malgrat) and in the relict bar system on the Maresme shelf (Serra et al. 1990, Serra and Sorribas 1993, Díaz and Maldonado 1989). The bars in $\mathrm{C} 1$ and $\mathrm{C} 2$ must have corresponded to a dynamic situation similar to the present one. However, transgressive conditions caused a retreat of the Tordera accreted riverbed from the Blanes Canyon head to its present position. The palaeochannels at the base of unit Sd1 to the NE and to the SW (Figs 6 and 7) indicate that the former courses of the River Tordera flowed in both directions. It is therefore possible to establish a relationship between the River Tordera and the Blanes Canyon during the last low stage of the sea level and the subsequent eustatic rise. At that time, the sedimentary contribution of the River Tordera constituted the main source of sediments to the Blanes Canyon and to the relict inner shelf sand bodies.

The B1 relict and the present littoral prisms of B2 can also be correlated with $\mathrm{Sd} 3$ and Sd3sup, respectively.

As regards sediment dynamics, the topography of the NE Blanes coast acts as a physical barrier against drift currents from the north. La Planassa High also constituted a barrier against drift currents from the NE during the last sea level low and subsequent rise (Figs 1and 10), which is evidenced by the lack of detrital sediment from the NE (Serra-Raventós and Got 1976). This argument is based on the high content of present and relict carbonatic facies (maerl) on the inner shelf between the Blanes Canyon and the coast (Serra 1976, ITGE 1989) and on their growth requirements (Bosence and Wilson 2003, Blake and Maggs 2003, Wilson et al. 2004). This finding contrasts sharply with the sand facies of the SW Tordera coast and the Maresme shelf, which is fed by River Tordera sediment (Serra 1976, Pedrosa-Pàmies et al. 2013).

The sedimentary and seismostratigraphic units obtained from the Tordera delta wells data and marine seismic profiles, respectively, are interpreted to be formed during the Holocene after correlation with the regional eustatic curves (Aloïsi 1986, Verdaguer 1983). The ages assigned to the sequence limits are represented in Figure 11. 
The erosive surface underlying sequence $\mathrm{Sd} 1$ is regionally traceable throughout the continental shelf because of its high erosive signature (PH, Fig. 8). This surface has been described by earlier works (Got 1973, Gámez et al. 2009, Ercilla et al. 2010), and has been interpreted in this work as the base of the transgressive accretionary system tract SD1 (Fig. 6). Chronologically, earlier works established the $\mathrm{PH}$ dates as $14.5 \mathrm{ky}$. In this work the base of the Sd1 unit (Fig. 8) has been assigned to $14 \mathrm{ky}$, and the top of Sd1 corresponding to $11.5 \mathrm{ky}$. Both ages are assigned after correlation with well P6-S5 and the eustatic curve (Figs 11 and 2).

$\mathrm{Sd} 311$ is composed of pelitic subunits, Sd3111 and Sd3112. The age of Sd3111 ranges between 8900 and 7500 years BP, during which the sea level rose between -33 and -17 m (P6-S5 well, Fig. 2). This unit consists of grey-blue clays and silts with traces of marine organisms and organic matter, and becomes thinner and coarser towards the delta plain.

Subunit $\mathrm{Sd} 3112$ is located between -13 and $-7.5 \mathrm{~m}$ (B-3-A well, Fig. 2) and ranges in age between 7600 and 6800 YBP. It was coeval with Sd3111 for less than 300 years. It consists of clay and silt with abundant organic matter but without marine bioclasts. The limit between $\mathrm{Sd} 3 \mathrm{p}$ and $\mathrm{Sd} 311$ at $7800 \mathrm{YBP}$ is equivalent to the maximum flooding surface at the Rhone and Llobregat deltas defined by Boyer et al. (2006) and Gámez et al. (2009). Above this level, Sd3p and Sd3 sup correspond to the top Tordera delta units. In accordance with the eustatic curve, the sea level rose up to $9 \mathrm{~m}$ above the $\mathrm{Sd} 3112$ unit. The absence of marine bioclasts suggests that $\mathrm{Sd} 3112, \mathrm{Sd} 3 \mathrm{p}$ and $\mathrm{Sd} 3$ sup are fluvio-deltaic units. Sd3111 and Sd3112 correspond to brackish and fresh coastal lagoon systems, respectively. These two lagoons were coeval during the delta plain progradation but were separated by the aforementioned granite structural high. When the brackish lagoon was flooded owing to the continuous rise in sea level, the sea was obstructed first by the granite high and subsequently by the prograding units, $\mathrm{Sd} 3 \mathrm{p}$ and $\mathrm{Sd} 3$ sup, which resulted in the downlap cover of the two lagoons.

\section{CONCLUSION}

The correlation between the sedimentary and seismic data from the delta and the inner shelf of the River Tordera system and their chronology enable us to define three depositional sequences of the Holocene $(\mathrm{Sd} 1, \mathrm{Sd} 2$ and $\mathrm{Sd} 3)$. These sequences are made up of several subunits that are characterized by their coarsening upwards, progradational and transgressive nature, and are environmentally conditioned by an unconformable pre-Holocene (Plio-Pleistocene) substrate or crystalline basement.

The coastal and marine sand bodies have been described as delta lobes (A1), the present prodelta (A2), the littoral prisms $(\mathrm{B} 1, \mathrm{~B} 2)$ and the relict bar ridges (C1, C2)\#. A1, C1-C2 and B1-B2 are, respectively, correlated with the deltaic sedimentary sequences, $\mathrm{Sd} 1$, $\mathrm{Sd} 2$ and $\mathrm{Sd} 3$.

The current rich and relict carbonate productivity (maerl) and the lack of detritic sediments on the inner and middle shelf between Lloret, La Planassa

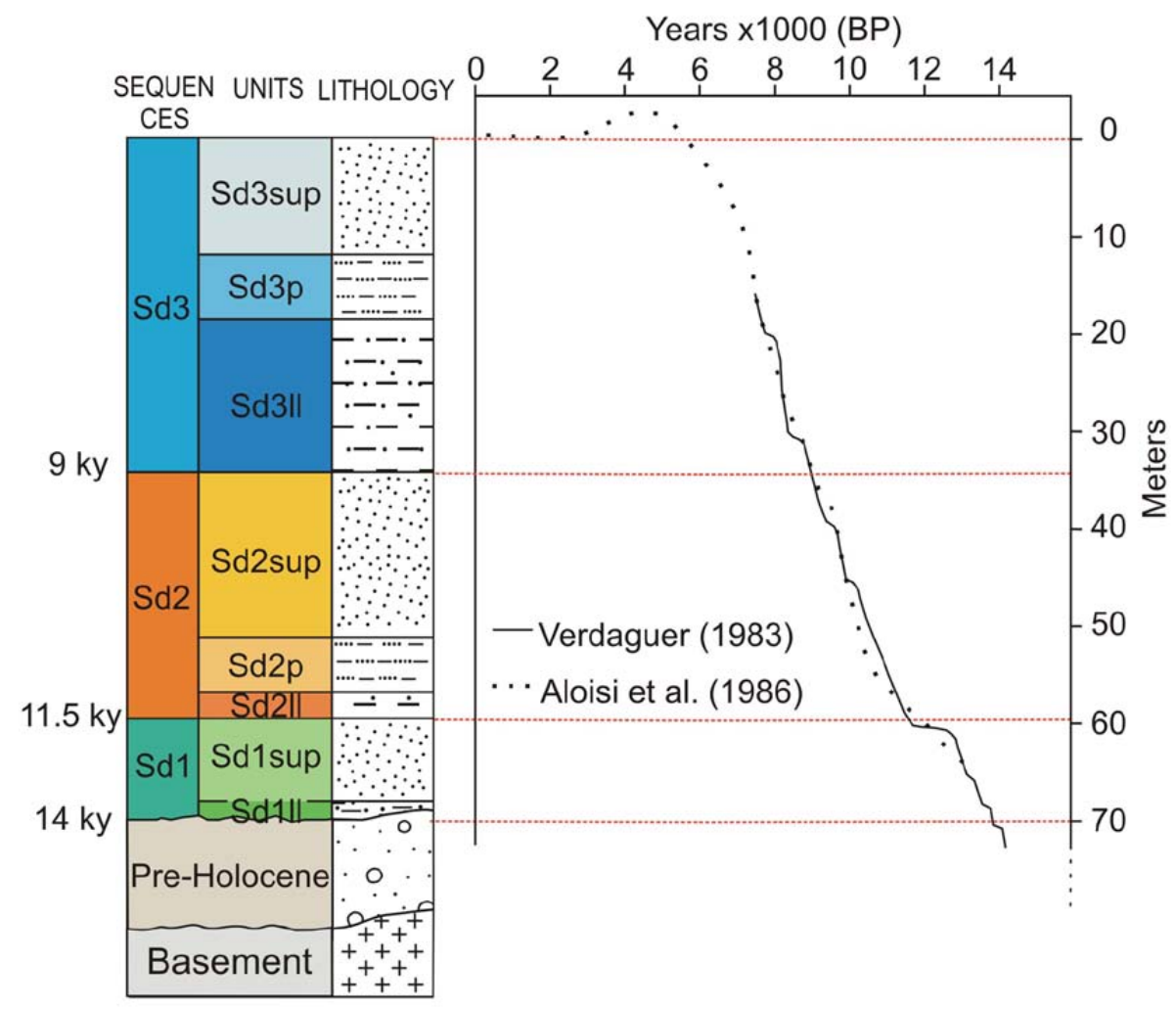

Fig. 11. - Standard reference section of the Tordera Delta Holocene sequences recorded at P6-S5 well. The location of the P6-S5 well can be seen in Figure 2. 
High and the Blanes Canyon head provides strong evidence of the absence of sedimentary drift transport from the NE.

The chronology of sequences $\mathrm{Sd} 1, \mathrm{Sd} 2$ and $\mathrm{Sd} 3$ is established after its correlation with the local sea level eustatic curve. The construction of the present delta began with unit SD1 at $14000 \mathrm{YBP}$.

\section{ACKNOWLEDGEMENTS}

This study was conducted within the framework of successive projects (ACA 2002, Sufi-ACA 2008, Pridesa-BeachMed (in Alfaro 2011)) in partnership with the Foundation Bosch Gimpera-UB. We gratefully acknowledge the support of Rafael Sardá (CEABCSIC), Marcel-lí Farran, Jorge Guillén (ICM-CSIC), Xavier Carreras (ACA-GC), Alex Marcuello and Beatriz Benjumea (Dept GG-UB), Albert Casas, Mahjoub Himi (Dept.PGPM-UB), Ferran Colombo (Dept EPiGM-UB), Luis Somoza (IGME) and Jose L. Sanz (IEO). The authors thank George Knorring for the English correction and the reviewers of the original manuscript of the present paper, especially doctors Ruth Duran and Pere Puig, for their constructive comments.

\section{REFERENCES}

Able K.W., Twichell D.C., Grimes C.B., et al. 1987. SideScanSonar as a tool for detection of the mersal fish habitats. Fish. Bull. 85(4): 725-744

ACA. 2002. Aquíffer del delta de la Tordera, Actualització del model hidrogeològic $\mathrm{i}$ anàlisis d'escenaris diversos per a una millor gestió de les aigües subterrànies. Annex 1: Descripció dels nous sondeigs. Informe intern de l'Agència Catalana de l'Aigua (ACA-GC).

Alfaro. 2011. Resultats del projecte BEACHMED-e Catalunya. Departament de Territori i Sostenibilitat de la Generalitat de Catalunya.

Aloïsi H.C. 1986. Sur un model de sédimentation deltaïque. Thèse doctoral. Universitat de Perpignan, $280 \mathrm{pp}$.

Alonso B., Duran R., Casas D, et al 2008. Gestion des stocks sableux interceptes par les ouvrages côtières et fluviaux. Recuperation du tranport solide. In: La Gestion Strategique de la défense des littoraux pour un développment soutenable des zones côtières de la Méditerranee. 3ème Cahier Tecnique Phace C, Mai 2008. Beachmed-2 Opération Cadre Regionale, pp. 119-133.

Ayranci K., Kosun E., Dashtgard S.E. 2010. Depositional facies and Three-Dimensional Architecture of the Goynuk Braid Delta, Gulf of Antalya, SW Turkey. CSPG Conferences, GeoCanadaWorking with the Earth, Canada's Energy Geocientists.

Bardaji T., Dabrio C.J., Goy J.L., et al. 1990. Pleistocene fan deltas in southestern Iberian Península: sedimentary controls and sealevel changes. Spec. Publis. Int. Ass. Sediment. 10: 129-151

Blake C., Maggs C.A. 2003. Comparative growth rates and internal banding periodicity of maerl species (Corallines, Rhodophyta) from northern Europe. Phycologia 42: 606-612.

Bogen J. 1983. Morphology and sedimentology of deltas in fjord and fjord valley lakes. Sedim. Geol. 36: 245-267. http://dx.doi.org/10.1016/0037-0738(83)90011-8

Bosence D., Wilson J. 2003. Maerl growth, carbonate production rates and accumulation rates in the NE Atlantic. Aquat. Conserv. Mar. Freshw. Ecosyst. 13: S21-S31 http://dx.doi.org/10.1002/aqc.565

Boyer J., Duvall C., Le Strat P., et al. 2006. High resolution stratigraphy and evolution of the Rhone delta plain during Postglacial time from subsurface drilling data bank. Mar. Geol. 222-223. 267-296. http://dx.doi.org/10.1016/j.margeo.2005.06.017

Catuneanu O., Abreu V., Bhattacharya J.P., et al. 2009. Towards the standardization of sequence stratigraphy. Earth Sci. Rev. 92(1-2): 1-33 http://dx.doi.org/10.1016/j.earscirev.2010.03.004

Checa A. Díaz J.L., Farràn M., et al. 1988. Sistemas deltaicos de los ríos Llobregat, Besós y Foix: modelos evolutivos transgresivos. Acta Geol. Hispánica 23: 241-255.

Condal M.T. Ullastres H. 1996. Anàlisis de les situacions sinòptiques més frequents en el desenvolupament de les rierades en el Maresme. Aiguats al Maresme- Revista Meteorològica Thetis, 47-51.

Copeiro del Villar E. 1982. Playas y Obras costeras en España. Revista de Obras Públicas. 531-547.

Corner G.D., Nordahl E., Munch-Ellingsen K., et al. 1990. Morphology and sedimentology of an emergent fjord-head Gilberttype delta: Alta Delta, Norway. Spec. Publs. Int. Ass. Sediment. 10: $155-168$. http://dx.doi.org/10.1002/9781444303858.ch8

Dabrio C.J., Bardaji T., Zazo C., et al. 1991. Effects of a sea-level changes on a wave-worked Gilbert-Type delta (Late Pliocene, Aguilas Basin, SE Spain). Cuad. Geol. Ibérica 15: 103-137.

Díaz J.L., Maldonado A. 1989. Transgressive sand bodies on the Maresme Continental Shelf, Western Mediterranean Sea. Mar. Geol. 91: 53-72. http://dx.doi.org/10.1016/0025-3227(90)90132-4

Díaz J.L., Ercilla G. 1993. Holocene depositional history of the Fluviá-Muga prodelta, northwestern Mediterranean Sea. Mar. Geol. 111(1-2): 83-92. http://dx.doi.org/10.1016/0025-3227(93)90189-3

Dunne L.A., Hepton M.R. 1984. Deltaic sedimentation in the Lake Hazar pull- appart basin, southeastern Turkey. Sedimentology 31: 401-412. http://dx.doi.org/10.1111/j.1365-3091.1984.tb00868.x

Duran R., Canals M., Sanz J.L., et al. 2013. Sediment dynamics and post-glacial evolution of the continental shelf around the Blanes submarine canyon head (NW Mediterranean). Prog. Oceanogr. 118: $28-46$. http://dx.doi.org/10.1016/j.pocean.2013.07.03

Duran R., Canals M., Sanz JL., et al. 2014. Morphology and sediment dynamics of the northern Catalan continental shelf, Northwestern Mediterranean Sea. Geomorphology 204: 1-20. http://dx.doi.org/10.1016/j.geomorph.2012.10.004

Ercilla G., Estrada F., Casas D., et al. 2010. The Masnou infralitoral sedimentary environment (Barcelona province, NW Mediterranean Sea): morphology and Holocene seismic stratigraphy. Sci. Mar. 74(1): 179-196. http://dx.doi.org/10.3989/scimar.2010.74n1179

Falgàs E. 2007. Hydrogeophysics as a multidisciplinary tool on aquifer appraisal: Focus on AMT Capabilities. Ph. D. Tesis. Univ. Barcelona, $219 \mathrm{pp}$

Font J., Julià A., Rovira J., et al. 1987. Circulación marina en la plataforma continental del Ebro determinada a partir de la distribución de masas de agua y los microcontaminantes orgánicos en el sedimento. Acta Geol. Hispànica 21-22: 483-489.

Galloway W.E. 1975. Process framework for describing the morphological and stratigraphic evolution of deltaic depositional systems. In: Broussard, M.L. (ed.), Deltas, 2nd edition. Houston Geological Society, Houston, TX, pp. 97-116.

Gámez D., Simó J.A., Lobo F.J., et al. 2009. Onshore- offshore correlation of the Llobregat deltaic system, Spain: Development of deltaic geometries under different relative sea-level and growth fault influences. Sediment. Geol. 217: 65-84. http://dx.doi.org/10.1016/j.sedgeo. 2009.03.007

Got H. 1973. Etude des correlations tectoniques-sedimentation au cours de l'histoire quaternaire du precontinenet Pyrineo-Catalan. These. Université des Sciences et Techniques du Languedoc. $294 \mathrm{pp}$

Grobas M. 2003. Variaciones del nivel del mar Mediterraneo occidental a partir de los datos suministrados por los mareógrafos. Tesina. Universitat Politècnica de Catalunya. 104 pp.

ITGE. 1989. Mapa Geológico de la Plataforma Continental Española y Zonas Adyacentes 1:200,000. Hoja 35/42E (Barcelona). Instituto Tecnológico GeoMinero de España, Madrid, Mem. Expl. $117 \mathrm{pp}$

Lastras G., Euroleon CSP. 2011. Understanding sediment dynamics of two large submarine valleys from seafloor data: Blanes and La Fonera canyons, NW Mediterranean Sea. Mar. Geol. 280: 20-39. http://dx.doi.org/10.1016/j.margeo.2010.11.005

Liquete C. 2008. La plataforma continental de Barcelona: análisis "source to snik" e impactos antropogénicos. Tesis doctoral. Universitat de Barcelona, $276 \mathrm{pp}$.

Liquete C., Canals M., De Mol B., et al. 2008. Quaternary stratal 
architecture of the Barcelona prodeltaic continental shelf (NW Mediterranean). Mar. Geol. 250: 234-250. http://dx.doi.org/10.1016/j.margeo.2008.01.014

Liu J.T., Huang J.-S., Hsu R.T., et al. 2000. The coastal depositional system of a small mountainous river: a perspective from grainsize distributions. Mar. Geol. 165: 63-86 http://dx.doi.org/10.1016/S0025-3227(99)00131-0

Martín-Vide J., Llasat M.C. 2000. Las precipitaciones torrenciales en Cataluña. Monografia Inundaciones. Serie Geográfica 9: $17-26$

Martini I.P. 1990. Pleistocene glacial fan deltas in southern Ontario, Canada. Spec. Publs. Int. Ass. Sediment. 10: 281-295 http://dx.doi.org/10.1002/9781444303858.ch16

Massari F., Parea G.C. 1990.Wave-dominated Gilbert-type gravel deltas in the hinterlans of the gulf of Taranto (Pleistocene southern Italy). Spec. Publs int. Ass. Sediment. 10: 311-331.

Macpherson J.G., Shanmugam G., Moiola R.J. 1987. Fan-delats and braid deltas: varieties of coarse-grained deltas. Bull. Geol. Soc. Am. 99: 331-340.

Orton G.J., Reading H.G. 1993. Variability of deltaic processes in terms of sediment supply, with particular emphasis on grain size. Sedimentology 40: 475-512. http://dx.doi.org/10.1111/j.1365-3091.1993.tb01347.x

Parra D. 2006. Anàlisis de la morfologia i estructura del delta submarí de la Tordera. Tesina de final de Carrera. Facultat de Geologia, Universitat de Barcelona.

Pedrosa-Pàmies R., Sanchez-Vidal A., Calafat A., et al. 2013. Impact of storm-induced remobilization on grain size distribution and organic carbon content in sediments from the Blanes Canyon area, NW Mediterranean Sea. Prog. Oceanogr. 118: 122-136. http://dx.doi.org/10.1016/j.pocean.2013.07.023

Pellegrini C., Maselli V., Cattaneo A., et al. 2015. Anatomy of a compound delta from the post-glacial transgressive record in the Adriatic Sea. Mar. Geol. 362: 43-59. http://dx.doi.org/10.1016/j.margeo.2015.01.010

Perea H. 2006. Falles actives I perillositat sísmica al marge nordoccidental del solc de València. Tesi doctoral. Universitat de Barcelona- RisKnat, 235 pp.

Perfibesa-ACA. 2001-2002. Pous dessaladora marge esquerre. Informe intern de l'Agència Catalana de l'Aigua (ACA).

Postma G.1990. Depositional architecture and facies of river and fan deltas: a synthesis. Spec. Plubls int. Ass. Sediment. 10: 13-27.

Riba O., Colombo F. 2009. Barcelona: la Ciutat Vella I el Poblenou: assaig de geologia urbana. Institut d'Estudis Catalans, Reial Acadèmia Ciències i Arts de Barcelona.

Rovira A., Batalla R.J., Sala M. 2005. Fluvial sediment budget of a Mediterranean river: the lower Tordera (Catalan Coastal Ranges, NE Spain). Catena 60: 19-42. http://dx.doi.org/10.1016/j.catena.2004.11.001

Serra J. 1976. Le Précontinent catalan entre le Cap Begur et Arenys de Mar: Structure et sédimentation récente. Thèse Doct. Univ. Paul Sabatier, Toulouse-Perpignan, $187 \mathrm{pp}$.

Serra J., Montori C. 2003. Morphology and sedimentary processes of the subaqueous Tordera River Delta, NW Mediterranean (Spain). Proceedings of coastals sediments, Tampa. Florida.

Serra J., Sorribas J. 1993. Las barras de arena infralitorales del Maresme: formación y cronologia. Geogaceta 14: 32-34.

Serra J., Verdaguer A., Canals M. 1985. Les differents types de modeles deltaiques du NE de la Peninsule Iberique. Rapp. Comm. Int. Mèdit. 29(2): 183-184.

Serra J., Sorribas J., Canals M. 1990. Abstracts IX Cong. Int R.C.M.N.S: 313.

Serra J., Valois X., Parra D. 2007. Estructura del prodelta de la Tordera (NO Mediterráneo) a partir del análisis sísmico de A.R. Geogaceta 41: 211-213

Serra-Raventós J., Got H. 1976. Notice explicative de la carte sedimentologique de St. Feliu de Guixols. Vie Milieu 26(1-B): 171-179.

Sorribas J., Serra J., Calafat A. 1993. Dynamic limits and sediment transport in the Maresme coast (Barcelona). Geogaceta 14: 24-26.

Sufi-ACA. 2008. Ampliació de la dessaladora de la Tordera: investigació de la captació d'aigua de mar mitjançant pous verticals. Tomo I Informe Hidrogeològico de limpieza y construcción de sondeos. Informe intern del Departament d'Infraestructures singulars i concertades de l'Agencia Catalana de l'Aigua (ACA).

Teixidó T. 2000. Caracterització del subsòl mitjançant sísmica de reflexió d'alta resolució. Ph. D. Tesis, Univ. de Barcelona, 253 pp.

Velasco V., Cabello P., Vazquez-Suñé E., et al. 2012. A sequence stratigraphic based geological model for constraining hydrogeological modeling. The urbanized area of the Quaternary Besòs delta (NW Mediterranean coast, Spain). Geol. Acta 10(4): 373-393.

Verdaguer A. 1983. La plataforma continental del Ebro: Un modelo sedimentario. Tesis Doct. Univ. de Barcelona, $422 \mathrm{pp}$.

Wilson S., Blake C., Berges J., et al. 2004. Environmental tolerances of free-living coralline algae (maerl): implications for European marine conservation. Biol. Conserv. 120: 283-293.

Wright L.D, Coleman J.M. 1972. River delta morphology: wave climate and the role of the subaqueous profiles. Science 176: 282-284.

http://dx.doi.org/10.1126/science.176.4032.282

Zúñiga D., Flexas M., Sanchez-Vidal A., et al. 2009. Particle fluxes dynamics in Blanes submarine canyon (Northwestern Mediterranean). Prog. Oceanogr. 82: 239-251.

http://dx.doi.org/10.1016/j.pocean.2009.07.002 